\title{
Fen Öğretiminde Etkileşimli Sınıf Ortamı Kurulumu: M-SES Kullanım Problemleri
}

\section{Establishing Interactive Classroom Environment in Science Instruction: Problems of M-SES Usage}

\author{
DOI : http://dx.doi.org/10.17556/jef.74863
}

\author{
Özkan YILMAZ*, Vehbi Aytekin SANALAN****
}

\section{Özet}

Öğrencinin öğrenme etkinlikleri sırasında kendi bilgilerini yapılandırabilmesi için gereken etkileşim ortamının kurulabilmesi amacıyla Mobil Etkileşim Sistemi (M-SES) tasarlanmıştır. Fen öğretiminde farklı derslerde uygulanan sistemin kullanımı sırasında bazı teknik problemlerin olduğu görülmüştür.Bu çalışma mobil sınıf içi etkileşim sistemi kullanımında karşılaşılan problemlerin belirlenmesi için öğrenci değerlendirmelerine bağlı bir nitel araştırmadır. Araştırma verileri öğrencilerle yapılan odak grup görüşmesi ile toplanmıştır. Yapılan görüşme ses kayıtları metin dosyası haline çevrilmiş ve içerik analizi kullanılarak temalar belirlenmiştir. Analiz ve temaların oluşturulmasında Nvivo bilgisayar paket programından yararlanılmıștır. Sistem kullanımda karşılaşılan problemler elde edilen sonuçlara göre belirlenmiştir.

Anahtar Sözcük: fen öğretimi, etkileşimli öğrenme, mobil sınıf içi etkileşim sistemi (M-SES)

\begin{abstract}
Mobile Classroom Interaction System (M-CIS) is designed for establish interactive learning environment, need student construct on their own knowledge, for student learning activity. The system, used in various science courses, has some technical problem when in use. This is a qualitative study to describe problems, students input, in mobile classroom interaction system use. Focus group interview method is used to get data collection. Voice records of interview are transcript to text and content analyses is used to identify themes. Nvivo PC software is used making analyze and identify themes. The problems, on system using, is showed according to the results.
\end{abstract}

Keywords: science instruction, interactive learning, mobile classroom interaction system (m-CIS)

\footnotetext{
* Yrd. Doç. Dr. Erzincan Üniversitesi, e-posta:ozkanyilmaz@erzincan.edu.tr ***** Yrd. Doç. Dr., Erzincan Üniversitesi , e-posta:sanalavi@gmail.com
} 


\section{Introduction}

One of aims of science education is improve scientific literacy ability of students who will be place in society. Students need to learn some abilities in order to reach to that aim. These are critical thinking and problem solving, explaining environmental events, keeping under control problem, understanding science-technology-society interaction, accommodating changing world conditions (Victor, 1985).

Computer and computer technologies have supported various educational fields in many years. Computer technologies allow students make more practice and feedback when they are studying. And also teacher get chance to analyses students' high thinking abilities. And can be record students' learning data (exam score, homework evaluation, projects...etc.). So teacher can evaluate own teaching strategies depend on students' learning outcomes. That evaluation provide to teacher can change own teaching methods (Gillani, 2003).

Some research, about using computer in learning and teaching activities, show that students' academic achievement and interest in the course and active participation of students have increase depend on computer using (Akçay, Aydoğdu, Yıldırım, \& Şensoy, 2005; Ak1, Gürel, Muştu, \& Oğuz, 2005; Aycan, Arı, Türkoğuz, Sezer, \& Kaynar, 2002; Coştu, Çepni, \& Yeşilyurt, 2002; Yumuşak \& Aycan, 2002).

Computer technologies are developing from day to day. One of good example is mobile phone. These devices have many specifications like a personal computer (PC). Today, people use their own personal mobile phones for arrange their life. For example, banking operation, surfing on web, e-mailing, as a credit card when shopping...etc.

Changing computer technologies affects educational technologies. The new one on educational technology is Audience Response System (ARS). That system is using as a classroom collaborator. Recently this system has used for different purpose in education. Research show that, the system using increase students' motivation on subject and also, positive effect on academic achievement (Beatty \& Gerace, 2009; Duggan, Palmer, \& Devitt, 
2007; Fies \& Marshall, 2006; Kay \& Knaack, 2009; Kenwright, 2009; MacGeorge, Homan, Jr, et al., 2008; MacGeorge, Homan, Jr., et al., 2008; Palmer, Devitt, Young, \& Morris, 2005; Penuel, Boscardin, Masyn, \& Crawford, 2007; Powe, Faulkenberry, Harmond, \& Cooper, 2009; Uhari, Renko, \& Soini, 2003).

Science instruction achievement increases with using right instruction strategy in right place. And, using computer technology makes that aim easy. Recently, using in instruction classroom communication technology developed to increase teacher-student interaction in learning environment.

In this study, designed mobile classroom interaction system was used to design effective learning environment in science instruction. But all technological system has some problem when using. This study is an attempt to describe problems in Mobile Classroom Interaction System using based on students input.

\section{Method}

This study applied in five different learning environments (physic lesson, chemistry lesson, biology lesson, and science instruction laboratory) with science teacher candidates in a small university in the east of Turkey. Student used m-CIS in during the one term. Five different classes were selected as a learning environment to apply m-CIS. About 225 students were used m-CIS. Six students were selected from each of classes. Qualitative research design was used in research. Focus group interview method was used to get data collecting. Students were answered interviewer question about m-CIS. Recorded interviews are about 150 minutes. These records were transcript to texts. These texts were analyzed with deductive method, and figured themes with use nVIVO Pc software.

\section{Mobile Classroom Interaction System (m-CIS)}

M-CIS similar to Audience Response System (ARS) but it has some differences from ARS. The most and important one is no cost for students. Because they are use their already owned mobile phones. These systems are using for communicating students each other and 
lecturer. Pre-study was used to determine if students have suitable mobile phone or not. Research has showed that students have appropriate mobile phone to m-CIS use (Yılmaz, Sanalan, \& Koç, 2009).

\section{Result}

Technical problems use of m-CIS based on students input are illustrated below figure 1 and explain the list.

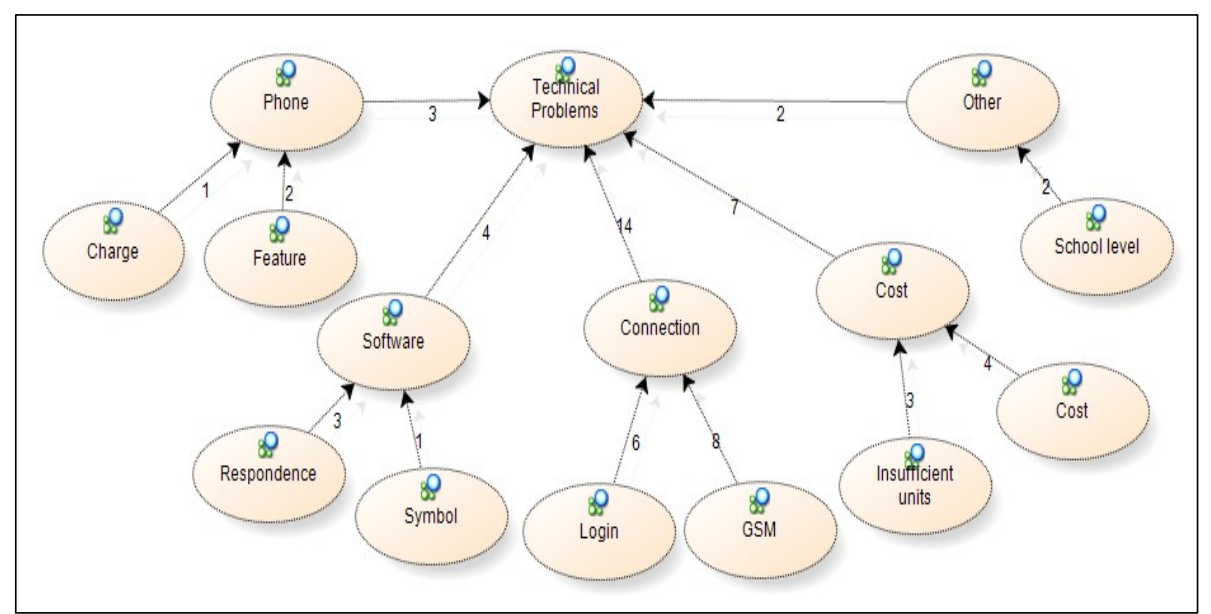

Figure 1: Technical problems use of m-CIS

As shown on figure 1, students' views are varying in five nodes. These nodes are phone, software, connection, cost, and other. In diagram, there are some link arrows and numbers. These numbers describes how many times referenced any node by students. Fundamental five nodes are explained below.

- Phone: Long time phone usage with the system cause battery run out and it needs to recharge. Some students don't have proper feature on their own phones.

- Software: When students give an answer to any question and sent to the system, sometimes they couldn't change their 
answer later. And if students want to write any symbol (like a mathematical symbol) the system doesn't support these specific characters.

- Connection: This node which is the most referenced by students includes login and GSM problems. If any student wants to use m-CIS she/he must use her/his personal user and password to login. Students sometimes couldn't login and use the system properly. Second problem is based on network. Students complain about their GSM company service. Poor service signal is lead to connection problem, so students couldn't use their phones properly to connect and login to mCIS.

- Cost: Usually students use pre-paid line. Sometimes they have no units to connect internet, so they couldn't use m-CIS. And the other problem is internet usage fee. Students have limit units and they don't want to use it for m-CIS.

- Other: This is not a technical problem but student said that mCIS couldn't use primary or secondary school. Because they are tender age and have no personal mobile phones..

\section{Discussion}

Controlling of students' learning activity is difficult for teachers, especially on science instruction laboratory. Science instruction laboratory is one of the important bases for scientific literacy. Students need more feedback when they are making experiment. For that purpose, m-CIS is designed for enhancing classroom interaction. Students are used m-CIS and evaluate technical using problem of test version of m-CIS.

First, students' mobile phones are very important fact on using $\mathrm{m}$-CIS. Their long stand-by times are important but any kind of powered by battery electronic device has using time limit. Before use $\mathrm{m}$-CIS students have to full charge their mobile phone. Pre-study is showed that students have appropriate mobile phones for using m-CIS but not definitely (Y1lmaz et al., 2009). This problem will be solved in time. The more multi-functional and longtime stand-by devices will be product in time. 
Second, students have some problem when they write mathematical symbol. This problem is maybe solving with new software. Also new software can allow for optional answer to students. So, students can change their answer even if sent.

Third, Students have connection problem. Source of connection problem of login is not a major problem. Because students are get their username and password for logging. And, logging procedures needs when just subject start. But sometimes when students want to login, there is network but no data line for internet. So, students complain about login problem. In addition, no network coverage problem can be appearing. Connectivity is important to mCIS for stable usability. These problems can be solve with developing technology or designed local network system.

Fourth, students are complaint about using price of GSM operator service. That is not a technical problem but it is effect users significantly. They offer a new and special device using with m-CIS. User friendly and no payment required system would be so good for users.

Fifth, Students think about m-CIS usability level of school. That is not problem as considered technical but students are right. M-CIS not designed for early age. System is designed for establishing multidimensional interaction in classroom in college level.

\section{Conclusion}

Technology of m-CIS is related to hardware and software. In this regard, students' mobile phones are important as a hardware fact. In time, student renews their mobile phones in parallel with advancing technology. In this way, new hardware bases a good system design in m-CIS. New phones also come with new features such as new and fast connection protocol service, fast browsing, long stand-by...etc. So, some problem that students proffered could be solve with new hardware allow for designing new software. The new software would solve limited usage area. Students would be having user friendly and 
functional user interface. However, designed a very powerful system it has to be low cost or free for user.

\section{References}

Akçay, S., Aydoğdu, M., Yıldırım, H. İ., \& Şensoy, Ö. (2005). Fen Eğitiminde İlköğretim 6. Sınıflarda Çiçekli Bitkiler Konusunun Öğretiminde Bilgisayar Destekli Öğretimin Öğrenci Başarısına Etkisi Kastamonu Eğitim Dergisi, 1(13), 103-116.

Akı, F. N., Gürel, Z., Muştu, C., \& Oğuz, O. (2005). Fen Bilimleri Eğitiminde Bilgisayar Kullanımının Öğrenciler Üzerine Etkisi. İstanbul Ticaret Üniversitesi Fen Bilimleri Dergisi Yll, 4(7), 47-58.

Aycan, Ş., Arı, E., Türkoğuz, S., Sezer, H., \& Kaynar, Ü. (2002). Fen ve Fizik Öğretiminde Bilgisayar Destekli Simülasyon Tekniğinin Öğrenci Başarısına Etkisi: Yeryüzünde Hareket Örneği. M.Ü. Atatürk Eğitim Fakültesi Eğitim Bilimleri Dergisi, 15, 57-70.

Beatty, I. D., \& Gerace, W. J. (2009). Technology-Enhanced Formative Assessment: A Research-Based Pedagogy for Teaching Science with Classroom Response Technology. Journal of Science Education and Technology, 18(2), 146-162. doi: DOI 10.1007/s10956-008-9140-4

Coştu, B., Çepni, S., \& Yeşilyurt, M. (2002). Kavram Yanılgılarının Giderilmesinde Bilgisayar Destekli Rehber Materyallerin Kullanılması. Paper presented at the V. Ulusal Fen Bilimleri ve Matematik Eğitimi Kongresi, ODTÜ Kültür ve Kongre Merkezi/ ANKARA.

Duggan, P. M., Palmer, E., \& Devitt, P. (2007). Electronic voting to encourage interactive lectures: a randomised trial. BMC Medical Education, 7(25).

Fies, C., \& Marshall, J. (2006). Classroom Response Systems: A Review of the Literature. Journal of Science Education and Technology, 15(1). doi: 10.1007/s10956-006-0360-1

Gillani, B. B. (2003). Learning Theories And The Desing Of E-Learning Environments. Lanham: University Press of America.

Kay, R., \& Knaack, L. (2009). Exploring the Use of Audience Response Systems in Secondary School Science Classrooms. Journal of Science Education and Technology, 18(5), 382-392. doi: DOI 10.1007/s10956-009-9153-7

Kenwright, K. (2009). Clickers in the Classroom. TechTrends, 53(1), 74-77.

MacGeorge, E. L., Homan, S. R., Jr, J. B. D., Elmore, D., Bodie, G. D., Evans, E., . . . Geddes, B. (2008). Student evaluation of audience response technology in large lecture classes. Education Tech Research Dev, 56, 125-145. doi: 10.1007/s11423-007-9053-6

MacGeorge, E. L., Homan, S. R., Jr., J. B. D., Elmore, D., Bodie, G. D., Evans, E., . . . Lichti, S. M. (2008). The Influence of Learning Characteristics on Evaluation of Audience Response Technology Journal of Computing in Higher Education, 19(2), 25-46. 
Palmer, E. J., Devitt, P. G., Young, N. J. D., \& Morris, D. (2005). Assessment of an electronic voting system within the tutoria setting: A randomised controlled trial [ISRCTN54535861]. BMC Medical Education, 5(24).

Penuel, W. R., Boscardin, C. K., Masyn, K., \& Crawford, V. M. (2007). Teaching with student response systems in elementary and secondary education settings: A survey study. Education Tech Research Dev, 55, 315-346. doi: 10.1007/s11423-006-9023-4

Powe, B. D., Faulkenberry, R. C., Harmond, L., \& Cooper, D. L. (2009). Evaluating the Use of an Audience Response Technology System to Collect Research Data among African American Elders. Ageing Int, 34, 60-66. doi: 10.1007/s12126-009-9037-4

Uhari, M., Renko, M., \& Soini, H. (2003). Experiences of using an interactive audience response system in lectures. BMC Medical Education, 3(12).

Victor, E. (1985). Science For The Elementary School (Fifth Edition ed.). New York: Macmillan Publishing Company, Inc.

Yılmaz, Ö., Sanalan, V. A., \& Koç, A. (2009, 6-8 May). An Evaluation Of Mlearning Applications. Paper presented at the 9th International Educational Technology Conference Ankara-Turkey.

Yumuşak, A., \& Aycan, Ş. (2002). Fen Bilgisi Eğitiminde Bilgisayar Destekli Çalışmanın Faydaları; Demirci (Manisa)'de Bir Örnek M.Ü. Atatürk Eğitim Fakültesi Ĕgitim Bilimleri Dergisi, 16, 197-204.

\section{Genişletilmiș Özet}

\section{Giriş}

Fen eğitiminin amaçlarından biri öğrencilerin birer fen okur-yazarı olabilmelerini sağlamaktır. Bunun için öğrencilere, kritik düşünebilme, problem çözme, bir problemi kontrol altında tutabilme, var olan çevresel olayları açıklayabilme gibi beceriler kazandırmak hedeflenir. Öğretimde belirlenen hedeflere ulaşabilmek için farklı strateji, yöntem ve teknikler kullanılmaktadır. Bunları yaparken öğretim ve öğrenmeyi desteklemek amacı ile farklı teknolojiler kullanılmaktadır. Özellikle öğrenme sırasında ihtiyaç duyulan dönüt-düzeltmenin sağlanmasında bilgisayar teknolojileri büyük kolaylık sunmaktadır. Yapılan çeşitli çalışmalar öğrenme-öğretme ortamında farklı amaçlarla kullanılan bilgisayar teknolojilerinin akademik başarı, derse karşı ilgi ve katılımda artış sağladığını göstermiştir. Yakın zamanda farklı öğrenme ortamlarında kullanılmaya başlanan Dinleyici Yanıt Sistemi (DYS) dönüt-düzeltme sağlaması yönüyle etkin bir bilgisayar teknolojisidir. Özellikle sınıf ortamında öğrencilerin derse karşı motivasyonlarının arttırılmasında ve akademik başarıda olumlu etki sağladığı yapılan araştırmalar sonucu ortaya konmuştur. Bu çalışmada, temeli DYS teknolojisine benzer olan ancak özel cihazlar yerine öğrencilerin sahip olduğu cep telefonlarının kullanımına dayalı tasarlanan Mobil Sınıf İçi Etkileşim Sisteminin fen öğretiminde kullanımı sırasında karşılaşılan teknik problemlerin neler olduğunun 
belirlenmesi amaçlanmıştır. Bu problemlerin neler olduğu öğrenci görüşlerine bağlı olarak değerlendirilmiştir.

\section{Metot}

Bu çalışma, fen öğretimine yönelik olarak fizik, kimya, biyoloji ve fen öğretimi laboratuvarı derslerinde yapılmıştır. M-SES bir dönem boyunca, Fen Bilgisi Öğretmenliği bölümünde öğrenim gören ortalama 225 öğrenci tarafından kullanılmıştır. Fizik, kimya, biyoloji derslerinden birer sınıf, laboratuvar dersinde ise iki farklı sınıf ortamı olmak üzere toplam beş farklı öğrenme ortamında m-SES uygulaması yapılmıştır. Her sınıftan üç kız ve üç erkek toplam altı öğrenci seçilerek odak grup görüşmesi yapılmıştır. Ortalama 150 dakikalık ses kaydı metin dosyası haline çevrilmiş ve nVIVO bilgisayar programında içerik analizi yapılarak sonuçlar temalar halinde sunulmuştur.

\section{Bulgular}

Sistem kullanımında karşılaşılan teknik problemler temelde beş grupta toplanmaktadır. $\mathrm{Bu}$ problemler; telefonla ilgili problemler, yazılımla ilgili problemler, bağlantı problemleri, kullanım maliyeti ve diğer başlıkları altında incelenmektedir. Telefonla ilgili olarak öğrenciler, telefon özelliklerinin yetersiz olduğu ve kısa sürede pilinin bitmesinden kaynaklı problemler yaşadıklarını belirtmiştir. Öğrenciler, yazılımla ilgili olarak, bir soruya cevap verirken özel simgeler (matematiksel semboller gibi) yazamadıklarını ve cevap yazdıktan sonra cevapları üzerinde değişikliklerin bazen sorun olduğunu belirtmiştir. Bir başka problem olarak, bazen sisteme girişte sıkıntı yaşadıklarını veya cep telefonları ile internet kullanımı esnasında şebeke ile bağlantı problemleri olduğu yönünde görüş belirtilmiştir. Sistem kullanımı için gereken maliyet öğrenciler tarafından görülen bir başka problemdir. Teknik bir problem olmamakla birlikte öğrenciler sistemin kü̧̈ük yaşlarda kullanılamayacağını belirtmişlerdir.

\section{Tartışma}

Fen öğretiminde etkileşimli sınıf ortamının kurulması ile iyi bir fen öğretiminin yapılabilmesi için tasarlanan m-SES'in öğrenci görüşlerine bağl1 değerlendirilmesi, sistemin geliştirilmesi ve sınıf içerisinde çok yönlü etkileşimin sağlanması için gereklidir. Bu anlamda elde edilen bulgular incelendiğinde bazı problemlerin olduğu görülmektedir. Telefonlarının bekleme sürelerinin kısa olması ve tasarlanan sistemle tam uyumlu çalışmaması yönünde belirtilen problem teknolojinin yeni olmasına bağlıdır. Sistem tasarlanırken yapılan ön çalışma ile genel anlamda telefonların uyumlu olduğu sonucu çıkmıştır. Ancak, bu durum yüzde yüz uyumluluk vardır şeklinde düşünülemez. Zamanla gelişen teknoloji, daha düşük maliyet daha fonksiyonel cep telefonlarının üretilmesini sağlayacağından bu problem kısa vadede çözülebilecek bir problemdir. M-SES kullanılırken yazılımdan kaynaklı bazı sınırılıklar öğrencilerin bir cevabı yazarken sıkıntı yaşamalarına sebep olmuştur. Bu problem yeni yazılımların geliştirilerek m-SES'in daha fonksiyonel olması ile çözülebilir. Toplamda 14 referans alan bağlantı problemi önemli bir diğer problemdir. Bağlantı yapılamadığı zaman etkileşimli bir sınıf 
ortamının kurulması düşünülemez. Bağlantı problemi cep telefonu ile hizmet sağlayıcı GSM şirketi arasında yaşanmış olması problemin çözümünün servis sağlayıcı şirketin daha iyi bir alt yapı ile hizmet vermesi ile mümkün olacağını göstermektedir. Diğer bir çözüm, cep telefonlarının m-SES'e kapalı bir ağ üzerinden her hangi bir servis sağlayıcı şirkete ihtiyaç duymadan bağlanabilmesini sağlamaktır. Kapalı yerel bir ağın kurulması bir diğer problem olan maliyeti de ortadan kaldırabilir. Son olarak, küçük yaş gruplarında sistemin kullanılamayacağı görüşü doğrudur. Sistem özellikle yükseköğrenim seviyesinde kullanılmak üzere tasarlandi.

\section{Sonuç}

Fen öğretiminde etkileșim sınıf ortamının kurulması amacı ile tasarlanan mSES temelde iki alanda eksikleri yer almaktadır. Donanım ve yazılım yönüyle sahip olduğu bu eksiklikler yeni teknoloji ve yazılımlarla çözülebilir niteliktedir. Bir diğer önemli unsur olan maliyet her teknolojik sistem gibi kullanıcılar için önemli bir engeldir. M-SES uygulamalarında, sistemin kullanımı mümkün olan en az maliyet veya sıfır maliyetle öğrenci veya öğretmenlerin hizmetine sunulmalıdır. 